\title{
Examination of the effect of type and quantity of sugar on main sensory parameters of homemade oat-flakes biscuit
}

\section{TÍMEA KASZAB ${ }^{1 *}$, BLANKA HALASI ${ }^{2}$ and ZOLTAN KOVACS ${ }^{1}$}

${ }^{1}$ Department of Measurements and Process Control, Faculty of Food Science, Szent Istvan University, 14-16 Somloi str., 1118 Budapest, Hungary

${ }^{2}$ Department of Food Preservation, Faculty of Food Science, Szent Istvan University, 29-43 Villányi str., 1118 Budapest, Hungary

\section{CONFERENCE FULL PAPER}

Received: January 31, $2020 \bullet$ Accepted: September 10, 2020

Published online: November 2, 2020

(C) 2020 The Author(s)

\begin{abstract}
The fiber intake is an important part of the human diet. The fiber-deficient nutrition may have long-term health problems. Oat (Avena sativa) is an excellent source of fiber and it has many health benefits due to its rich vitamin and mineral composition. Oats are used as flour and flakes in the food industry. The oat-flakes can be used in a variety of cakes, but it can be also consumed as breakfast cereals or porridge.

The objective of our work was to determine the effect of the sugar content and sugar types on main sensory parameters of oat-flakes biscuit. During the experiments, six different types of biscuit were made with the addition of white or brown sugar at three different concentration levels. The moisture content, color, and the frangibility of the samples were analyzed during the 4-day storage period. The sensory evaluation of the biscuit samples was also performed on the first day of storage.

The parameters of the rupture test and color measurement did not show significant changes during the storage, but the individual types of biscuits made of different types and quantities of sugar could be well distinguished. Results of sensory evaluation showed significant differences in frangibility, structure and stickiness parameters.
\end{abstract}

\section{KEYWORDS}

oat-flakes, biscuit, sugar, sensory evaluation

*Corresponding author. E-mail: kaszab.timea@szie.hu 


\section{INTRODUCTION}

The common oat (Avena sativa) is a species of cereal grain mainly grown for its utilization for human consumption as oatmeal as well as for livestock feed. Oat has always been regarded as a health promoting food without clear knowledge of its specific health related effects. However, today it is known for its effects on satiety and retarded absorption of nutrients as well as a deterrent of various disorders of the gastrointestinal tract. These beneficial effects are chiefly due to the soluble fiber content of oats (Daou \& Zhang, 2012). Today oats are among the richest and most economical sources of soluble dietary fiber. The present interest in soluble oat fiber originated from reports that showed that dietary oats can help in lowering cholesterol postprandial blood glucose level as well as modifying immune response and reducing risk of colon cancer (Wood, 1986; Skendi et al., 2003; Lazaridou \& Biliaderis, 2007).

In the food industry there are several ways to use the meal of oats. Consuming oats as flakes is perhaps the most popular today. The oatmeal is obtained by extrusion from the whole eye, so it contains all its components. Used for decoration of bakery products, whole or minced, but also suitable for enrichment or densification of dough as oatmeal flour (Szabó, 1982).

More healthy food product was developed with high ß-glucan and oat content in the ÉKINAIK (Élelmiszer-tudományi Kutatóintézet, Nemzeti Agrárkutatási és Innovációs Központ (Food Science Research Institute)). The aim of the research was to detect the change of the Bglycan as dietary fiber during the research. Finally, muffin was produced with oat feed. The oat feed content of the muffin was 50\% (MTA, 2007).

In order to elucidate the effect of sugar composition on the water sorption and softening properties of cookie, three types of sugar composition (sugar, sugar-trehalose, and sugar-sorbitol) were employed as an ingredient of cookie, and softening temperature of the cookie samples, adjusted to various water contents, was investigated using thermal rheological analysis. The softening temperature decreased linearly with increasing water content of the cookie samples. The results suggest that sugar composition plays an important role in the softening properties of cookie samples (Kawai et al., 2014).

Experiment was made to find an optimal recipe for biscuits with the addition of pollen, and at the same time investigate the physical, chemical and health-promoting properties in obtained products (Krystyjan et al., 2015).

The sensory characteristics are one of the most important criteria for shopping, as they have a great impact on consumers. The main purpose of consumer sensory testing is to determine how well the product meets the consumer's expectations. So it can be used to develop a product that is best seen by consumers (Lawless \& Heimann, 2010). The objective of our work was to determine the effect of the sugar content and sugar types on rheological and sensory parameters of oat-flakes biscuit.

\section{MATERIALS AND METHODS}

\section{Biscuit samples}

During the experiments six different types of biscuit were made with the addition of white or brown sugar at three different concentration levels $(0.10,0.15$, and $0.20 \mathrm{~kg})$. Each group consisted of 15 samples. Two parallel 4 -day short-time storage experiments were performed on two consecutive weeks. The storage parameters were as the follows (Table 1): 
Table 1. Storage parameters of oat-flakes biscuits

\begin{tabular}{ccc}
\hline Experiments & Temperature & Relative humidity \\
\hline 1. & $27 \pm 0.3^{\circ} \mathrm{C}$ & $22.2 \pm 2.5 \%$ \\
2. & $27.1 \pm 0.9^{\circ} \mathrm{C}$ & $27.9 \pm 2.5 \%$ \\
\hline
\end{tabular}

\section{Methods}

The moisture content of the samples was determined with classical drying method in VENTICELL (MMM Medcenter, München, Germany) drying chamber. The samples were dried at $105{ }^{\circ} \mathrm{C}, 24$ h until constant weight (Kaszab et al., 2008).

The color of the biscuits on the given day was also measured by ColorLite sph850 (ColorLite $\mathrm{GmbH}$, Katlenburg-Lindau, Germany) spectrophotometer. Test results were obtained as CIE (Commission Internationale de la Éclargie) $\mathrm{L}^{*}, \mathrm{a}^{*}, \mathrm{~b}^{*}$ color properties. The instrument settings were " $2{ }^{\circ}$ standard observer" and "standard illuminant D65". Results of each measurement were calculated from the average of three measurements by the ColorLite equipment. The aim was to control the similarity of the groups.

The frangibility of the biscuits was measured by TA.XT.Plus (Stable Micro System, Surrey, UK) precision penetrometer, with $\mathrm{P} 0.5 \mathrm{~S}$ type, $0.5 \mathrm{col}$ diameter stainless steel ball. Test settings were as follows: pretest speed at $1 \mathrm{~mm} / \mathrm{s}$, test speed at $0.1 \mathrm{~mm} / \mathrm{s}$ and distance at $6 \mathrm{~mm}$. A $5 \mathrm{~kg}$ load cell was used and the maximum rupture force $\left(F_{M A X}\right)$ and the distance of maximum rupture force $\left(D_{M A X}\right)$ were measured. Furthermore, the gradient of the curve up to maximum force $\left(F_{M A X} / D_{M A X}\right)$ and the area below the rupture curve, such as work $(A)$ were determined.

During the sensory evaluation, the aim was to rank the groups based on the sensory parameters. These parameters were as the follows: shape, thickness, color, texture, global odour intensity, frangibility, stickiness, sweet taste intensity, general aspect. The samples were evaluated by 21 consumers, with 12 women and 9 men between the ages of 21 and 45 years. All the patterns on the unstructured scale had to be placed between the positive and the negative end of the given property based on nine properties. The full length of the scale was $100 \%$, the distance between the beginning of the scale and the sample mark was measured. Finally, the samples in a 0-100 point system were scored.

The measured rheological properties values were evaluated by R-Studio Version 1.1.414 (R-Studio, 2018). After data reduction, a normality test (Shapiro-Wilk Test) was run on results of the samples. The equality of variances was checked by ANOVA. Furthermore, TukeyHSD test $(P<0.05)$ was used for detecting the significant differences between the groups (Reiczigel et al., 2014). Sensory attributes were predicted based on the results obtained with mechanical tests parameters by the means of partial least square (PLS) regression (Kvalheim, 2009). The PLS models are quantified by root mean standard error of calibration (RMSEC), root mean standard error of prediction (RMSEP) and coefficient of determination $\left(R^{2}\right)$ between the predicted and measured parameters. Leaving one-out (LOO) cross-validation procedure was used in this work.

\section{RESULTS AND DISCUSSION}

The moisture content was calculated by drying combined with mass measurement. The moisture content increased in the white sugar biscuits and decreased in the brown sugar samples during the short-time storage period. 
Before the rupture test the CIE L*a*b* color parameters were determined on each measuring day. Significant change was not found in the color parameters during the storage at both experiments. The frangibility of the biscuit samples were detected during the rupture test. From the determined rheological parameters the gradient $\left(F_{M A X} / D_{M A X}\right)$ was the strongest in the function of the storage time (Fig. 1). The error bar diagram reveals at $95 \%$ confidence interval the average and the standard deviation of the groups at both experiments. The standard deviation of group with lower sugar quantity was higher.

Decreasing was not found in the value of the gradient, however, a decrease was observed with the increasing of the sugar content at both series. The ANOVA and the TukeyHSD test showed significant differences among the three different sugar concentrations in the case of both white sugar and brown sugar (Table $2 \mathrm{~A}$ ). The $F_{M A X}, D_{M A X}$, and area $(A)$ showed similar results to the gradient, however, the least significant difference was found to be significant in the $D_{M A X}$ values according to the TukeyHSD test (Table 2B). Table 3 shows the TukeyHSD test results of the maximum rupture force $\left(F_{M A X}\right)$ and the area $(A)$.

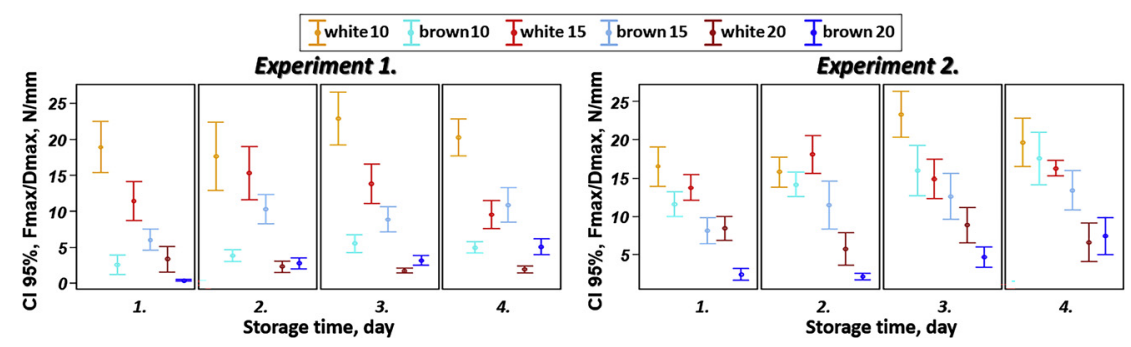

Fig. 1. The gradient $\left(F_{M A X} / D_{M A X}\right)$ (average and the $95 \%$ confidence interval) in the function of the storage time, (experiments from left to right: 1. and 2.)

Table 2. TukeyHSD test results of gradient $\left(F_{M A X} / D_{M A X}\right)$ and distance $\left(D_{M A X}\right)(P=0.05)$

\begin{tabular}{|c|c|c|c|c|c|c|c|c|c|c|c|c|c|c|c|c|c|c|c|c|c|c|c|}
\hline \multicolumn{6}{|c|}{ Fmax/Dmax (exp. 1.) } & \multicolumn{6}{|c|}{ Fmax/Dmax (exp. 2.) } & \multicolumn{6}{|c|}{ Dmax (exp. 1.) } & \multicolumn{6}{|c|}{ Dmax (exp. 2.) } \\
\hline & $\begin{array}{l}\text { 울 } \\
\frac{8}{2} \\
\frac{\pi}{3}\end{array}$ & & & $\begin{array}{l}\text { 군 } \\
5 \\
5 \\
0 \\
5\end{array}$ & 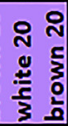 & & لِّ & & 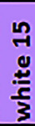 & & 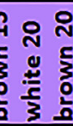 & & 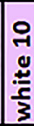 & & تِّ & & 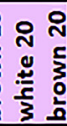 & & 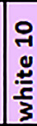 & $\begin{array}{l}\text { 울 } \\
5 \\
3 \\
0 \\
\text { 5. }\end{array}$ & 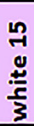 & 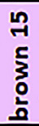 & 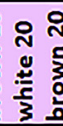 \\
\hline white 10 & & & & & & white 10 & & & & & & white 10 & & & & & & white 10 & & & & & \\
\hline brown 10 & + & & & & & brown 10 & + & & & & & brown 10 & - & & & & & brown 10 & - & & & & \\
\hline white 15 & + & + & & & & white 15 & + & - & & & & white 15 & - & - & & & & white 15 & - & - & & & \\
\hline brown 15 & + & + & + & & & brown 15 & + & + & + & & & brown 15 & - & - & - & & & brown 15 & + & - & + & & \\
\hline white 20 & + & - & + & + & & white 20 & + & + & + & + & & white 20 & + & + & + & + & & white 20 & + & + & + & - & \\
\hline brown 20 & + & - & + & + & - & brown 20 & + & + & + & + & - & brown 20 & + & + & + & + & - & brown 20 & + & + & + & + & + \\
\hline
\end{tabular}


Table 3. TukeyHSD test results of maximum rupture force $\left(F_{M A X}\right)$ and area $(A)(P=0.05)$

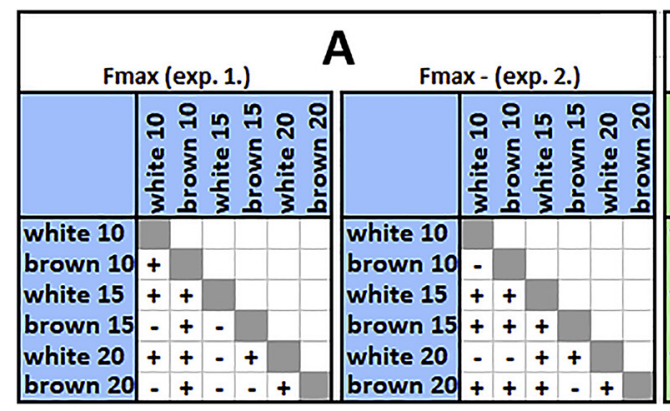

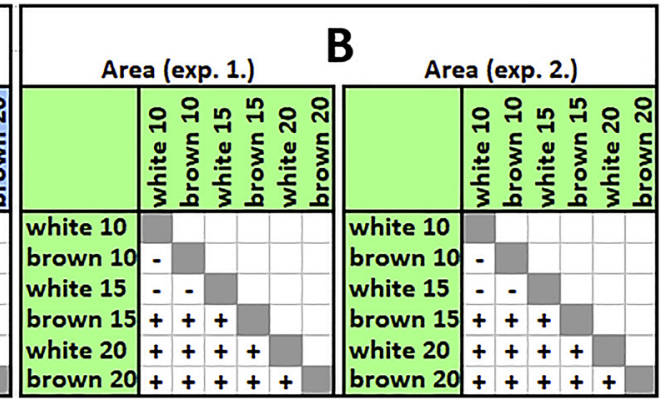

During the sensory analysis all judges tested all 6 products (Fig. 2). Fig. 3 shows the average of the points of each sensory property. The lower point means the more positive properties. Based on the results, it can be concluded that the consumers were able to distinguish each group

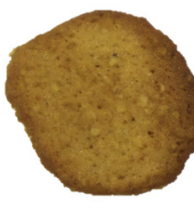

White 10

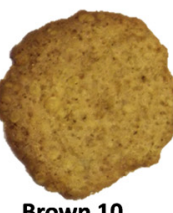

Brown 10

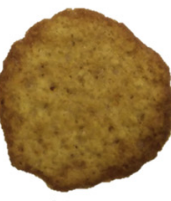

White 15

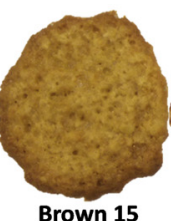

Brown 15

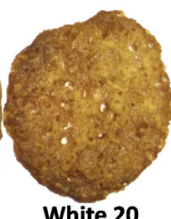

White 20

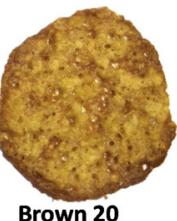

Brown 20

Fig. 2. Samples from the 6 different recipes

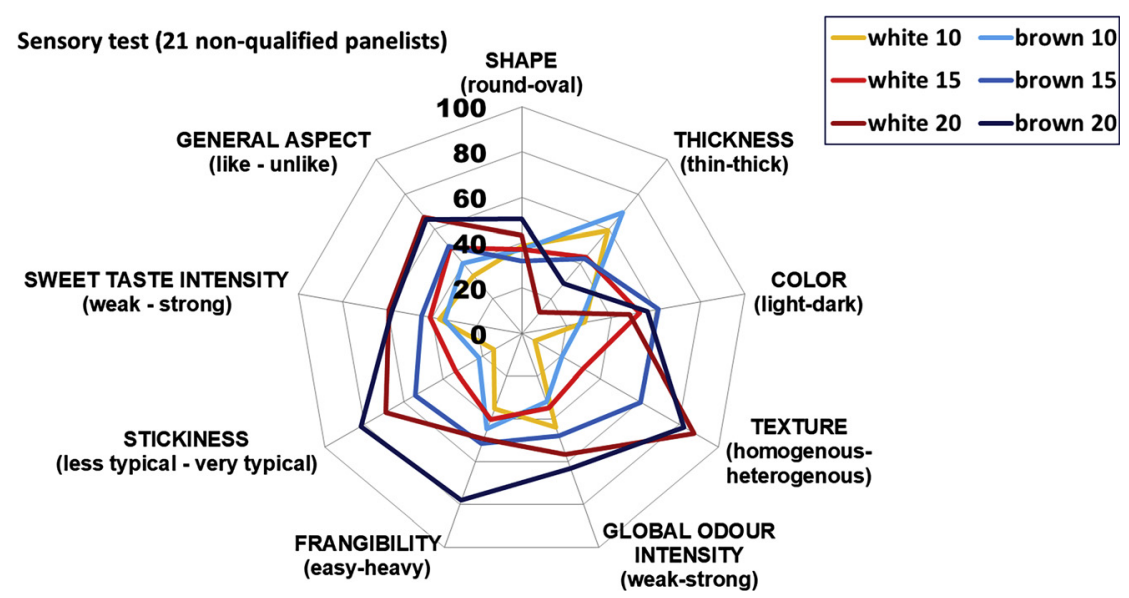

Fig. 3. The results of the sensory evaluation based on 9 sensory properties 
more firmly on the basis of the properties "thickness", "structure", and "stickiness". In contrast, however, the samples were placed in a narrower range in terms of "color" and "sweet taste intensity" properties. This means that they could not clearly distinguish the samples based on these properties.

The texture properties showed the strongest significant difference between the groups based on the judging by points. The groups were separated successfully based on the stickiness and texture properties according to the increasing sugar concentration. The groups did not separate well based on the frangibility; however, the original aim of this work was to analyze the frangibility of the biscuits during storage (Table 4). The reason for this was the soft, sticky stock of higher sugar concentration samples.

The frangibility, texture, and stickiness properties were applied to estimate based on the $F_{M A X}, D_{M A X}, F_{M A X} / D_{M A X}$, and $A$ rheological parameters by Texture Analyzer. Results of the first day samples of both experiments were applied to the PLS regression (Table 5).

Table 4. TukeyHSD test results of frangibility, texture, and stickiness $(P=0.05)$
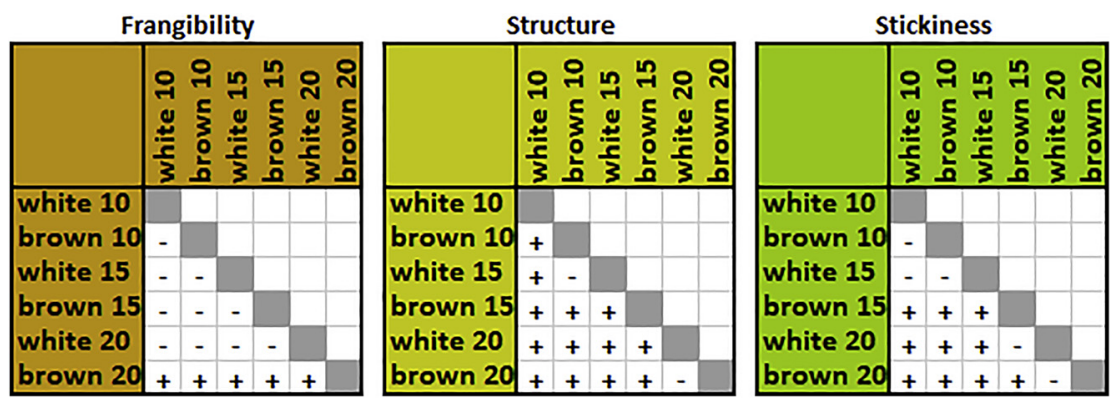

Table 5. PLS calibration and cross-validation (leave one out (LOO)) to the sensory properties of oat-flakes biscuits based on the results of the maximum rupture force, distance of maximum rupture force, gradient (ratio of maximum rupture force and distance) and area

\begin{tabular}{|c|c|c|c|c|c|c|}
\hline \multirow[b]{2}{*}{ Experiment } & \multirow[b]{2}{*}{ Sensory property } & \multirow[b]{2}{*}{ LV (number) } & \multicolumn{2}{|c|}{ Calibration } & \multicolumn{2}{|c|}{ Cross-validation } \\
\hline & & & $R^{2}$ & RMSEC $^{\mathrm{a}}$ & $R^{2}$ & RMSEP $^{\mathrm{b}}$ \\
\hline \multirow[t]{3}{*}{1.} & Frangibility $^{c}$ & 4 & 0.6544 & 7.534 & 0.5116 & 8.851 \\
\hline & Texture & 4 & 0.6798 & 17.94 & 0.5802 & 20.53 \\
\hline & Stickiness $^{c}$ & 4 & 0.6743 & 14.02 & 0.5851 & 15.81 \\
\hline \multirow[t]{3}{*}{2.} & Frangibility $^{c}$ & 4 & 0.8335 & 5.555 & 0.7790 & 6.395 \\
\hline & Texture ${ }^{c}$ & 4 & 0.5965 & 19.56 & 0.4665 & 22.45 \\
\hline & Stickiness ${ }^{c}$ & 4 & 0.6229 & 15.05 & 0.5645 & 16.17 \\
\hline \multirow[t]{3}{*}{1.} & Frangibility $^{\mathrm{d}}$ & 4 & 0.7061 & 3.285 & 0.6234 & 3.713 \\
\hline & Texture ${ }^{\mathrm{d}}$ & 4 & 0.7030 & 19.34 & 0.6196 & 21.86 \\
\hline & Stickiness ${ }^{\mathrm{d}}$ & 4 & 0.7058 & 12.94 & 0.6231 & 14.62 \\
\hline 2. & Frangibility $^{\mathrm{d}}$ & 4 & 0.6066 & 3.700 & 0.4461 & $\begin{array}{c}4.384 \\
\text { (continued) }\end{array}$ \\
\hline
\end{tabular}


Table 5. Continued

\begin{tabular}{|c|c|c|c|c|c|c|}
\hline \multirow[b]{2}{*}{ Experiment } & \multirow[b]{2}{*}{ Sensory property } & \multirow[b]{2}{*}{ LV (number) } & \multicolumn{2}{|c|}{ Calibration } & \multicolumn{2}{|c|}{ Cross-validation } \\
\hline & & & $R^{2}$ & RMSEC $^{\mathrm{a}}$ & $R^{2}$ & RMSEP $^{\mathrm{b}}$ \\
\hline \multirow{5}{*}{1.} & Texture $^{\mathrm{d}}$ & 4 & 0.6479 & 20.57 & 0.4708 & 25.15 \\
\hline & Stickiness $^{\mathrm{d}}$ & 4 & 0.6531 & 13.69 & 0.4788 & 16.73 \\
\hline & Frangibility $^{\mathrm{e}}$ & 4 & 0.8454 & 5.390 & 0.7648 & 6.636 \\
\hline & Texture $e^{e}$ & 4 & 0.7824 & 12.03 & 0.6650 & 14.92 \\
\hline & Stickiness ${ }^{\mathrm{e}}$ & 4 & 0.6531 & 11.02 & 0.6846 & 13.53 \\
\hline \multirow[t]{3}{*}{2.} & Frangibility $^{\mathrm{e}}$ & 4 & 0.8454 & 5.423 & 0.7398 & 7.137 \\
\hline & Texture ${ }^{\mathrm{e}}$ & 4 & 0.7824 & 10.59 & 0.7439 & 12.97 \\
\hline & Stickiness $^{\mathrm{e}}$ & 4 & 0.7907 & 9.746 & 0.7568 & 11.89 \\
\hline
\end{tabular}

${ }^{\text {a }}$ Root mean square error of calibration.

${ }^{b}$ Root mean square error of prediction.

${ }^{c}$ Estimation based on maximum rupture force, distance of maximum rupture force, gradient, area at white, and brown sugar groups.

${ }^{\mathrm{d}}$ Estimation based on maximum rupture force, distance of maximum rupture force, gradient, area at white sugar groups.

e Estimation based on maximum rupture force, distance of maximum rupture force, gradient, area at brown sugar groups. LV: latent variable.

The results showed the best estimations to the rheological sensory properties of biscuits with brown sugar based on the $F_{M A X}, D_{M A X}, F_{M A X} / D_{M A X}$, and $A$ rheological parameters at two parallel experiments. The coefficient of determination of cross-validation $\left(0.6650 \leq R^{2} \geq 0.7648\right)$ means that there is an acceptable relationship between the predicted and measured variables.

Fig. 4 shows the results of the brown sugar groups of the estimation of the frangibility, texture, and stickiness sensory properties of experiment 2 . The estimations contain the parameters of calibration and leave one out (LOO) cross-validation in Fig. 4.
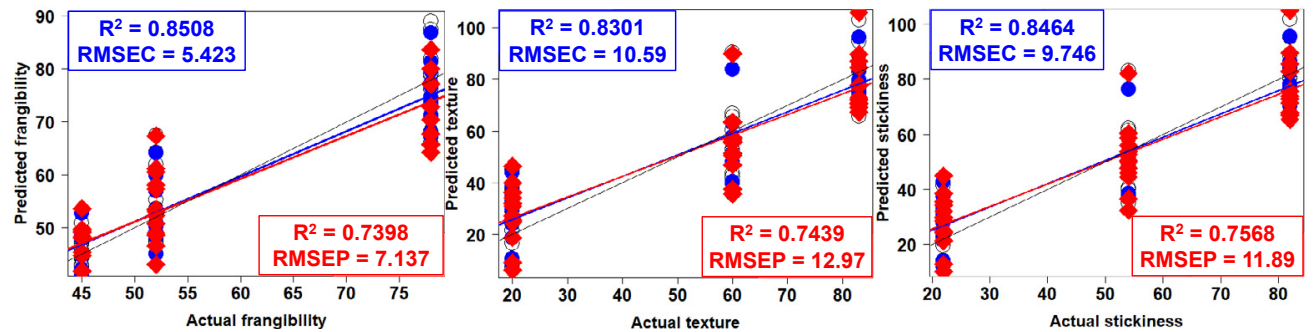

Fig. 4. Results of the brown sugar groups of the estimation of the frangibility, texture, and stickiness sensory properties of experiment 2 based on maximum rupture force, distance of maximum rupture force, gradient, and area 
The results of PLS regression may be influenced by the consumer habits and/or nontrained panelists as well. Data of a well-trained panel might have given higher $R^{2}$ and lower RMSEC/ RMSEP values.

\section{CONCLUSION}

The objective of our work was to determine the effect of the sugar content and sugar types on rheological and sensory parameters of oat-flakes biscuit. The determined parameters of rheological measurement did not reveal large-scale change during the short-time storage, however, significant differences were found in the rheological parameters in the case of the white and brown sugar. The best descriptive parameter was the gradient of the curve until the maximum rupture force $\left(F_{M A X}\right)$. The $F_{M A X}, D_{M A X}, F_{M A X} / D_{M A X}$, and $A$ parameters are capable of distinguishing the structure of biscuits depending on the different quantities of sugar and sugar types. Based on the results of the sensory evaluation it can be stated that among the 9 sensory aspects the rheological properties show a significant difference in the different recipes. These sensory properties were estimated based on the $F_{M A X}, D_{M A X}, F_{M A X} / D_{M A X}$, and $A$. The texture, frangibility, and the stickiness sensory properties of biscuits with brown sugar content are estimated successfully based on the rheological parameters at two parallel experiments.

\section{REFERENCES}

Daou, C. and Zhang, H. (2012). Oat beta-glucan: its role in health promotion and prevention of diseases. Comprehensive Reviews in Food Science and Food Safety, 11: 355-365.

Kaszab, T., Firtha, F., and Fekete, A. (2008). Influence of non-ideal storage conditions on carrot moisture content loss. Progress in Agricultural Engineering Sciences, 4(1): 61-75.

Kawai, K., Toh, M., and Hagura, Y. (2014). Effect of sugar composition on the water sorption and softening properties of cookie. Food Chemistry, 145: 772-776.

Krystyjan, M., Gumul, D., Ziobro, R., and Korus, A. (2015). The fortification of biscuits with bee pollen and its effect on physicochemical and antioxidant properties in biscuits. LWT - Food Science and Technology, 63(1): 640-646.

Kvalheim, O.M. (2010). Interpretation of partial least squares regression models by means of target projection and selectivity ratio plots. Journal of Chemometrics, 24: 496-504.

Lawless, H.T. and Heimann, H. (2010). Sensory evaluation of food, 2nd ed. Springer. https://doi.org/10. 1007/978-1-4419-6488-5.

Lazaridou, A. and Biliaderis, C.G. (2007). Molecular aspects of cereal $\beta$-glucan functionality: physical properties, technological applications and physiological effects. Journal of Cereal Science, 46: 101-118.

MTA Mezőgazdasági Kutatóintézetének Közleményei 2007/2 XIX. Évf. 2. szám, 16-17. o., Martonvásár.

Reiczigel J., Harnos A., and Solymosi N. (2014). Biostatisztika nem statisztikusoknak, javitott utánnyomás, Pars Kft., Budapest.

Skendi, A., Biliaderis, C.G., Lazaridou, A., and Izydorczyk, M.S. (2003). Structure and rheological properties of water soluble $\beta$-glucans from oat cultivars of Avena sativa and Avena by santina. Journal of Cereal Science, 38: 15-31. 
Szabó L. (1982). A zab, Magyarország kultúrflórája IX. kötet, Pázsitfúfélék II. füzet, Akadémiai Kiadó, Budapest.

Wood, P.J. (1986). Oat beta-glucan: structure, location and properties. In: Webster (Ed.), Oats: chemistry and technology. American Association of Cereal Chemistry, St. Paul, USA. pp. 121-152.

Open Access. This is an open-access article distributed under the terms of the Creative Commons Attribution 4.0 International License (https://creativecommons.org/licenses/by/4.0/), which permits unrestricted use, distribution, and reproduction in any medium, provided the original author and source are credited, a link to the CC License is provided, and changes - if any - are indicated. (SID_1) 